\title{
Phenoloxidase is involved in the immune reaction of Helix lucorum to parasitic infestation by dicrocoeliid trematode
}

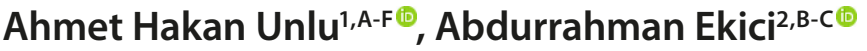 \\ ${ }^{1}$ Veterinary Division, Vocational School of Gevas, Van Yuzuncu Yil University, Van, Turkey \\ 2 Department of Parasitology, Faculty of Medicine, Van Yuzuncu Yil University, Van, Turkey \\ $A$ - Research concept and design, B - Collection and/or assembly of data, C - Data analysis and interpretation, \\ $D$ - Writing the article, E-Critical revision of the article, F- Final approval of the article
}

Ahmet Hakan Unlu, Abdurrahman Ekici. Phenoloxidase is involved in the immune reaction of Helix lucorum to parasitic infestation by dicrocoeliid trematode. Ann Agric Environ Med. 2021; 28(3): 426-429. doi: 10.26444/aaem/140319

\begin{abstract}
Introduction. Phenoloxidases are known to play a role in the immune defences of arthropods and molluscs. In the invertebrates, phenoloxidases mediate three major physiologically important processes: sclerotization, wound healing, and defence reactions. Helix lucorum serve as the first intermediate host for the larval stages of dicrocoeliid trematodes which infects animals as well as human beings.

Objective. The aim of the study is to investigate the effect of larval forms of dicrocoeliid trematodes to phenoloxidase acitivity in H. lucorum, Linneaus, 1758, in Bitlis, Turkey. The effect of the snail's shell colour to phenoloxidase activity was also investigated.

Materials and method. Land snails $(n=200)$ were collected by hand from their natural habitats during the period May June 2019 in Bitlis, Turkey. Evaluation of the process was performed by measuring immune reaction of the snails against larval forms of dicrocoeliid trematodes. Phenoloxidase activity assay was carried out using a spectrophotometer device based on 3,4-Dihydroxy-L-phenylalanine (L-dopa) hydrolysis.

Results. The natural infection rate of the land snails with the developmental stages of dicrocoeliid trematodes was $20 \%$. Phenoloxidase activity was found to be significantly higher $\left({ }^{*} p<0.05\right)$ in larval forms of dicrocoeliid trematodes infected snails when compared with non-infected snails. No effect of shell colours to phenoloxidase activity was observed.

Conclusions. To the best of the authors' knowledge, this study is the first to report that the phenoloxidase system is involved in the immune reaction of Helix lucorum to parasitic infestation by larval forms of dicrocoeliid trematodes.
\end{abstract}

\section{- Key words}

dicrocoeliidae, parasite, phenoloxidase activity, snail

\section{INTRODUCTION}

Phenoloxidase (PO) is a copper-dependent enzyme that appears to be widespread in many microorganisms, plants, and animals [1-4] and its activity has been utilised as an immune indicant in several species of molluscs [5-8]. PO can be found in the haemolymph in its inactive form called prophenoloxidase (proPO) and is activated by external components of some microorganisms [9]. Melanisation is in a relation with $\mathrm{PO}$ and requires the activation of proPO in invertebrates $[10,11]$.

The Dicrocoeliidae is a large family that includes more than 400 species [12]. Dicrocoeliid trematodes (DTs) can be found in the liver, bile ducts, gall bladder, pancreas, and intestines of their final hosts [13]. The most well-known member of the family is Dicrocoelium dendriticum, also known as the small lancet fluke usually seen in the bile ducts of ovine. Cercariae and metacercariae, which are larval stages of D. dendriticum, occur in the first intermediate host - snails, and in second intermediate hosts - ants, respectively. Zoonotically, humans could be the final host and may become infected with D. dendriticum without showing any clinical symptoms [14].

Address for correspondence: Ahmet Hakan Unlu, Veterinary Division, Vocational School of Gevas, Yuzuncu Yil University, Van, Turkey

E-mail: ahakanunlu@yyu.edu.tr

Received: 31.05.2021; accepted: 19.07.2021; first published:09.08.2021
Helix lucorum, known by the common name 'big garden snail' is a terrestrial pulmonate gastropod mollusc. Helix $s p p$. are of interest to industrial farming, in demand with the food, pharmaceutical, and other industries [15]. Besides its economic value, land snails are intermediate host to DTs which infect mammals, reptiles, amphibians, and birds. The main physical barrier of H. lucorum is the shell and mucus which cover the soft body of the snail. The internal defence mechanisms of molluscs involve; phagocytosis, nodule formation, pearl formation, encapsulation, atrophy, and necrosis. Humoral parts of molluscan immunity are consisted by lysosomal activity, lectins, and the phenoloxidase system [16].

The effect of the larval forms of DTs parasitisation on PO activity in the land snail has not yet been determined. In the present study, PO activity were measured in the haemolymph of big garden snails, Helix lucorum, which were naturally infected with DTs. PO levels were also determined in the light and dark shell coloured snail's haemolymph.

\section{MATERIALS AND METHOD}

Sampling and identification. Samples of terrestrial snails Helix lucorum $(\mathrm{n}=200)$ were collected by hand picking from their natural habitats, rural areas close to streams during 
the period May - June 2019 in Bitlis, Turkey. Only adult size snails were selected for the experiment. The snails were identified according to Schütt [17]. Larval stages of DTs were recognised under the microscope (Leica DM500, Germany) and identified according to Olsen [13].

Experiment set-up. The land snails were kept in moistened handmade plastic terrariums for haemolymph collection and dissection. All the snails were numbered $1-200$. Haemolymph collection was performed according to Renwrantz et al. [18]. Haemolymph samples were kept in $0.5 \mathrm{ml}$ eppendorf tubes on ice and were used freshly for the phenoloxidase activity assay. Following the haemolymph collection, the snails were removed from their shells and digestive glands were disrupted. The dissection process was performed according to Segun [19]. In order to avoid the effect of natural infestation with nematodes, the snails were examined for nematode infection by microscopic examination of the digestive glands.

Phenoloxidase (PO) activity assay. PO activity assay was performed using non-infected and DT infected Helix lucorum. PO activity in the non-infected snails was used as a control. The colour effect (melanisation) on the snail immunity was analysed using light and dark morph of the non-infected snails.

PO activity assay was carried out using the classical spectrophotometric procedure based on 3,4-DihydroxyL-phenylalanine (L-dopa) hydrolysis and performed as previously described, with some modifications [20]. Firstly, $40 \mu \mathrm{l}$ of haemolymph was mixed with $40 \mu \mathrm{l}$ of $1 \mathrm{X}$ phosphate buffered saline (PBS) on ice. A total of $80 \mu \mathrm{l}$ sample aliquots were placed in cuvettes containing $280 \mu \mathrm{l}$ of ic-cold distilled water and $40 \mu \mathrm{l}$ of $1 \mathrm{X}$ PBS. In short, $40 \mu \mathrm{l}$ of ice cold L-DOPA (Sigma-Aldrich, Germany) were added to each well to start the reaction. $\mathrm{PO}$ oxidizes L-DOPA which results in an increase in the absorbance of the samples. Photometric measurement was performed immediately to the prepared cuvettes at $490 \mathrm{~nm}$ in a spectrophotometer device (SpectroScan 60DV) resulting $0 \mathrm{~h}$ values. The covered cuvettes were incubated at $30^{\circ} \mathrm{C}$ in an incubator for 45 mins (species specific time which the increase in absorbance is linear, data not shown). After the incubation period, the photometric measurement process was performed again at $490 \mathrm{~nm}$. PO activity value was then calculated by subtracting the $0 \mathrm{~h}$ value from the species specific time value. The change in the absorbance was recorded as microunits. All the measurements were performed in triplicate.

Statistical analysis. All experiments were performed in triplicate. The mean and standard error (SE) were calculated. The data acquired from the results of the PO acitivity assay were statistically analyzed by one-way analysis of variance (one-way ANOVA) to identify differences between groups. Differences were considered statistically significant when ${ }^{*} \mathrm{p}<0.05$.

\section{RESULTS}

Identification and prevalence. Second-generation sporocysts (A, B) and cercariae (A, B, C, D) of dicrocoeliid trematodes (DTs) were found in the digestive glands of Helix lucorum at the rate of $20 \%$ (Fig. 1). Nematode infections were determined in three land snails and these samples were excluded from the study to avoid any interference.

Levels of phenoloxidase (PO) activity The existence of PO activity was shown in the haemolymph of Helix lucorum. The PO activity levels in larval forms of DT infected snails were significantly $\left({ }^{\star} \mathrm{p}<0.05\right)$ higher compared to those noninfected (Fig. 2). Shell colours of 41 non-infected snails were significantly lighter or darker than the rest. PO activity levels of dark shell coloured snails tended to be slightly higher. However, no statistically significant effect of colour was observed as regards the PO activities in the snails (Fig. 2); therefore, the colour of the snail shell and its effect on the snail's immune defence were not taken into consideration.

\section{DISCUSSION}

In the invertebrates, POs mediate physiologically important processes, such as wound healing, sclerotization, and most important immune defence reactions and comprehensive information about the role of PO in immunity is notably available for insects and crustaceans $[10,21,22]$. The role of the $\mathrm{PO}$ activity in controlling infection by trematode parasites is still poorly understood in molluscs, and clarification of this process is important for understanding the defence mechanisms present in the intermediary host. The current study provides new data on PO activity in the haemolymph of Helix lucorum species which have a commercial value.

The land snail, Helix lucorum, can be found in the whole of Anatolia, Iran, and Caucasia, as well as in Central France. These land snails are abundant in humid conditions, riverine grasslands, forests, gardens, and orchards [23]. Dicrocoeliid trematodes (DTs) are parasitic organisms of amphibians, reptiles, and mammals, including humans, and land snails are the first intermediate host for DTs $[13,14]$. Previous prevalence studies conducted in Turkey showed that the infection rates of the larval stages of DTs in H. lucorum were $4.6 \%, 7 \%, 4.9 \%$, and 22\% in Eskisehir, Bartin, Afyonkarahisar, and Van, respectively [24-26]. In the presented study, the infection rate with the larval stages of DT was found to be $20 \%$ in Bitlis, Turkey (Fig. 1).

In the current study, the immune defence of the land snail was quantified by directly measuring the PO activity using L-DOPA as a substrate. When considering the results of PO activity, there was a significant difference observed in larval forms of DT infected snails compared with those non-infected (Fig. 2). PO activity could be increased due to detrimental and harmful effect of larval forms of DT in the land snail, since POs mediates wound healing and immune reactions in invertebrates $[3,10]$.

In the present study, only adult size snails were collected in a two months period since the PO activity of molluscs could differ due to the effect of different ages and seasons $[27,28]$. Land snails reach a definite adult size, and then stop growing. Therefore, unless they are raised in a laboratory, it is not possible to determine the exact age of the snails.

Invertebrates employ phenoloxidase for melanin biosynthesis. Melanisation is considered a natural immune response in invertebrates due to it 's role in eradicating invader pathogens $[29,30]$. Shell colour polymorphism is a widespread characteristic feature that can be seen in various land snails $[31,32]$. It has been reported that no statistically 

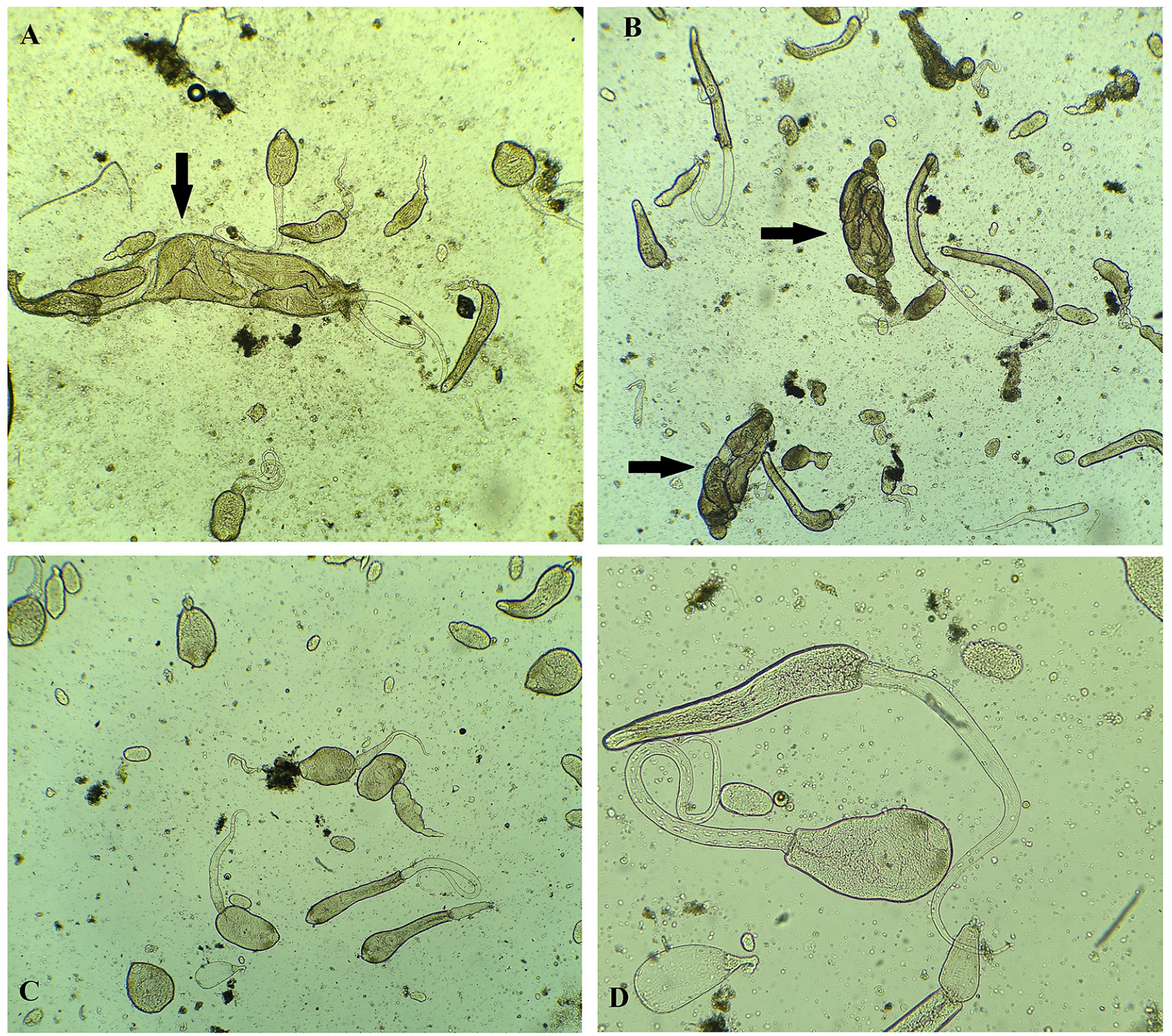

Figure 1. Second-generation sporocysts (A, B) and cercariae (A, B, C, D) of dicrocoeliid trematodes (DTs). Arrows show second-generation sporocysts. Magnification: $A, B$ and $C ; \times 40$ and $D ; \times 100$.

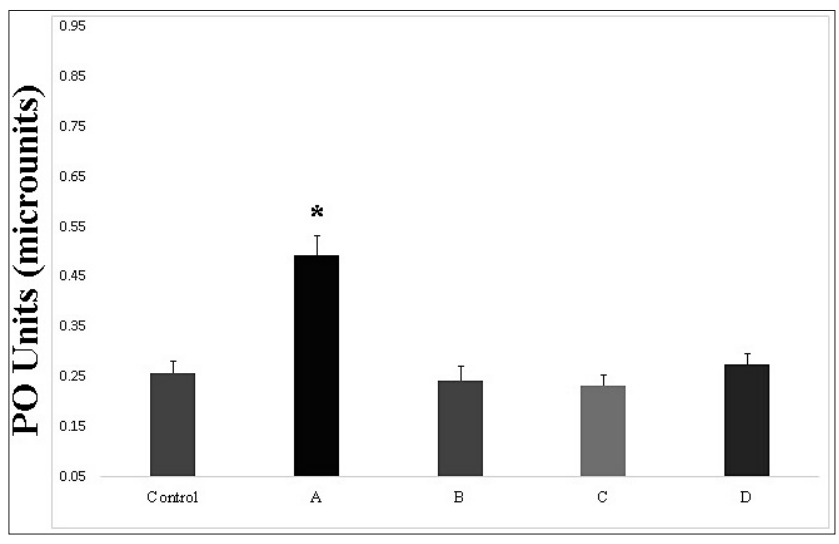

Figure 2. Phenoloxidase (PO) activity present in the haemolymph of Helix lucorum; non-infected (control), larval stages of dicrocoeliid trematodes (DTs) infected (A), non-infected medium shell coloured (B), non-infected light shell coloured (C), and non-infected dark shell coloured (D). Datas represent mean + standart error (SE). Asterisk shows statistically significant difference $\left({ }^{*} p<0.05\right)$ significant effects of colour were found in PO activity between light and dark morph of helicid snail species $[33,34]$. In the present study, shell colours of 41 non-infected snails were significantly lighter or darker than the rest, likewise, there was no statistically significant effect of shell colour observed in PO activity. However, slight increases were detected in dark shell coloured snails compared with the values found in light shell coloured samples (Fig. 2).

\section{CONCLUSION}

The study shows that phenoloxidase (PO) is involved in the immune reaction of Helix lucorum to parasitic infestation by larval forms of dicrocoeliid trematode (DT). This finding supports the idea that a PO mediated immune defence mechanism could be important for the land snail to survive while larval forms of the parasite exist in its digestive glands. 
Future work will help to reveal how PO-dependent defence mechanisms take place in the land snail, and more about the vital relations between the larval forms of DTs and the land snail in nature.

\section{REFERENCES}

1. Cerenius L, Söderhäll K. Immune properties of invertebrate phenoloxidases. Dev Comp Immunol. 2021; 104098. https://doi. org/10.1016/j.dci.2021.104098

2. Lu A, Zhang Q, Zhang Q, et al. Insect prophenoloxidase: the view beyond immunity. Front Physiol. 2014; 5: 252. https://doi.org/10.3389/ fphys.2014.00252

3. Stączek S, Grygorczuk K, Zdybicka-Barabas A, et al. Different faces of phenoloxidase in animals. Postepy Biochemi. 2017; 63(4): 315-325.

4. Jukanti A. Function(s)/Role(s) of Polyphenol Oxidases. In: Polyphenol Oxidases (PPOs) in Plants. Singapore: Springer; 2017. https://doi. org/10.1007/978-981-10-5747-2_5

5. Le Clec'h W, Anderson TJ, Chevalier FD. Characterization of haemolymph phenoloxidase activity in two Biomphalaria snail species and impact of Schistosoma mansoni infection. Parasites Vectors. 2016; 9(1): 1-11. https://doi.org/10.1186/s13071-016-1319-6

6. Leicht K, Jokela J, Seppälä O. An experimental heat wave changes immune defense and life history traits in a freshwater snail. Ecol Evol. 2013; 3(15): 4861-4871. https://doi.org/10.1002/ece3.874

7. Quinn EA, Malkin SH, Rowley AF, et al. Laccase and catecholoxidase activities contribute to innate immunity in slipper limpets, Crepidula fornicata. Dev Comp Immunol. 2020; 110: 103724. https://doi. org/10.1016/j.dci.2020.103724

8. De Melo ES, Brayner FA, Junior NCP, et al. Investigation of defense response and immune priming in Biomphalaria glabrata and Biomphalaria straminea, two species with different susceptibility to Schistosoma mansoni. Parasitol Res. 2020; 119(1): 189-201. https:// doi.org/10.1007/s00436-019-06495-4

9. Wang L, Song X, Song L. The oyster immunity. Dev Comp Immunol. 2018; 80: 99-118. https://doi:10.1016/j.dci.2017.05.025

10. Noothuan N, Amparyup P, Tassanakajon A. Melanization inhibition protein of Penaeus monodon acts as a negative regulator of the prophenoloxidase-activating system. Dev Comp Immunol. 2017; 72: 97-102. https://doi.org/10.1016/j.dci.2017.02.014

11. Cerenius L, Lee BL, Söderhäll K. The proPO-system: pros and cons for its role in invertebrate immunity. Trends Immunol. 2008; 29(6): 263-271. https://doi.org/10.1016/j.it.2008.02.009

12. Pojmańska, T. Family Dicrocoeliidae Looss, 1899 . Keys to The Trematoda Volume. 2008; 3: 233-260. https://doi.org/10.1079/9780851995885.0000

13. Olsen OW. Animal parasites: their life cycles and ecology. New York: Dover Publishing; 1986.

14. Otranto D, Traversa D. A review of dicrocoeliosis of ruminants including recent advances in the diagnosis and treatment. Vet Parasitol. 2002; 107(4): 317-335. https://doi.org/10.1016/s0304-4017(02)00121-8

15. Conte R. Heliciculture: purpose and economic perspectives in the European community. IST Journal, 2015.

16. Gliński Z, Jarosz J. Molluscan immune defenses. Arch Immunol Ther Exp. 1997; 45(2-3): 149-155.

17. Schütt H. Turkish Land Snails, 1758-2000. Vollständig Revidierte und Erweiterte Auflage, Natur \& Wissenschaft, 2005.
18. Renwrantz L, Schäncke W, Harm H, et al. Discriminative ability and function of the immunobiological recognition system of the snail Helix pomatia. J Comp Physiol. 1981; 141(4): 477-488.

19. Segun AO. Land snails (Dissection guides of common tropical animals). Ethiope Publications, 1973.

20. Seppälä O, Jokela J. Maintenance of genetic variation in immune defense of a freshwater snail: role of environmental heterogeneity. Evolution. 2010; 64(8): 2397-2407. https://doi.org/10.1111/j.15585646.2010.00995.x

21. Rajendran S, Vasudevan S. Activation of prophenoloxidase and hyperglycemia as indicators of microbial stress in the blue swimmer crab Portunus pelagicus. Mar Pollut Bull. 2020; 160: 111711. https:// doi.org/10.1016/j.marpolbul.2020.111711

22. Nakhleh J, El Moussawi L, Osta MA. The melanization response in insect immunity. Adv Insect Physiol. 2017; 52: 83-109. https://doi. org/10.1016/bs.aiip.2016.11.002

23. Yildirim MZ, Kebapci U, Gumus BA. Edible snails (Terrestrial) of Turkey. Turk J Zool. 2004; 28(4): 329-335.

24. Eser M, Kartal K, Navruz FZ. The Prevalence Of Dicrocoeliidae (Digenea) Larval Stages In The First Intermediate Host Helix Lucorum, 1758 In Eskisehir And Bartin Provinces Of Turkey. Eskisehir Tech Univ J Sci Tech. 2021; 10(1): 38-43. https://doi.org/10.18036/estubtdc.714841

25. Kartal K, Mustafa K, Mustafa E. The Prevalance of larval stages of small liver fluke Dicrocoelium dendriticum in the first intermediate host Helix lucorum Linnaeus, 1758 (Mollusca: Pulmonata) in Afyonkarahisar district. Kocatepe Vet J. 2015; 8(1): 51-55. https://doi. org/10.18036/estubtdc.714841

26. Unlu AH, Bilgic HB, Eren H, Karagenc T. Prevalence of Larval-Stage Dicrocoeliidae (Digenea) Trematodes in Helix lucorum (Mollusca: Pulmonata) in Van Province. Turk J Parasitology. 2017; 41(4): 204-207. https://doi.org/10.5152/tpd.2017.5444

27. Gerdol M, Gomez-Chiarri M, Castillo MG, et al. Immunity in molluscs: recognition and effector mechanisms, with a focus on bivalvia. In Advances in Comparative Immunology. Cham: Springer; 2018. p. 225-341. https://doi.org/10.1007/978-3-319-76768-0

28. Zhou S, Zhao L, Zhao T. Phenol oxidase activity of Oncomelania snails in different ages and seasons. Chin J Zoonoses. 2010; 26(9): 856-861.

29. Amparyup P, Charoensapsri W, Tassanakajon A. Prophenoloxidase system and its role in shrimp immune responses against major pathogens. Fish Shellfish Immunol. 2013; 34(4): 990-1001. https://doi. org/10.1016/j.fsi.2012.08.019

30. Quinn EA, Malkin SH, Rowley AF, et al. Laccase and catecholoxidase activities contribute to innate immunity in slipper limpets, Crepidula fornicata. Dev Comp Immunol. 2020; 110: 103724. https://doi. org/10.1016/j.dci.2020.103724

31. Ito S, Konuma J. Disruptive selection of shell colour in land snails: a mark-recapture study of Euhadra peliomphala simodae. Biol J Linn Soc. $2020 ; 129(2):$ 323-333. https://doi.org/10.1093/biolinnean/blz168

32. Saenko SV, Schilthuizen M. Evo-devo of shell colour in gastropods and bivalves. Curr Opin Genet Dev. 2021; 69: 1-5. https://doi.org/10.1016/j. gde.2020.11.009

33. Scheil AE, Hilsmann S, Triebskorn R, et al. Shell colour polymorphism, injuries and immune defense in three helicid snail species, Cepaea hortensis, Theba pisana and Cornu aspersum maximum. Results Immunol. 2013; 3: 73-78. https://doi.org/10.1016/j.rinim.2013.06.002

34. Scheil AE, Hilsmann S, Triebskorn R, et al. Shell colouration and parasite tolerance in two helicoid snail species. J Invertebr Pathol. 2014; 117: 1-8. https://doi.org/ 10.1016/j.jip.2014.01.003 